\title{
CHEMICAL COMPOSITION, ANTIOXIDANT AND ANTIMICROBIAL ACTIVITY OF THE TURMERIC ESSENTIAL OIL (Curcuma longa L.)
}

\author{
Jelena S. Stanojević, Ljiljana P. Stanojević*, Dragan J. Cvetković, Bojana R. Danilović
}

(ORIGINAL SCIENTIFIC PAPER)

UDC 633.8:665.5:66.048.6

Faculty of Technology, Leskovac, Serbia

In the present work, essential oil has been obtained by Clevenger-type hydrodestillation from grounded curcuma rhizome (Rhizoma Curcumae) (Turkey) with hydromodulus $1: 5 \mathrm{~m} / \mathrm{V}$ during 180 minutes. The qualitative and quantitative composition of the oil was determined by GC-MS and GC-FID spectrometry. The antioxidant activity of the obtained oil was determined using DPPH assay just after adding DPPH radical and after $20 \mathrm{~min}, 30 \mathrm{~min}$ and $45 \mathrm{~min}$ incubation with radical. The antimicrobial activity was determined using a discdiffusion method. The yield of the essential oil was $0.3 \mathrm{~cm}^{3} / 100 \mathrm{~g}$ plant material. Eight compounds were identified. The major ones were ar-turmerone $(22.7 \%)$, turmerone $(26 \%)$ and curlone $(16.8 \%)$. The best antioxidant activity showed the oil incubated for 45 minutes with DPPH radical. EC50 values for the obtained oil were $1.784 \mathrm{mg} / \mathrm{cm}^{3}$ (without incubation), $0.098 \mathrm{mg} / \mathrm{cm}^{3}$ (after 20 minutes), $0.072 \mathrm{mg} / \mathrm{cm}^{3}$ (after 30 minutes) and $0.045 \mathrm{mg} / \mathrm{cm}^{3}$ (after 45 minutes incubation with radical). The oil showed the best antimicrobial activity against Candida albicans. The results indicate that turmeric essential oil is an extremely strong antioxidant and antimicrobial (antifungal) agent with potential application in the food and pharmaceutical industries as a safer alternative to the synthetic antioxidants and antimicrobial agents.

\section{Introduction}

Essential oils are complex mixtures of secondary plant metabolites. They are highly concentrated, volatile, oily distillates. Essential oils are found in all plant parts (flowers, barks, roots, leaves, peels, seeds) due to the activity of endogenous and exogenous secretory plant tissues. Among many other methods, essential oils could be obtained by hydrodistillation, steam, water/steam distillation, expression and extraction with supercritical carbon dioxide $[1,2]$. Owing to their aroma, odor and a plethora of beneficial effects, they are widely used in perfumes, cosmetics, aromatherapy and nutrition $[3,4]$.

Curcuma longa L., also known as curcuma (turmeric, indian shaffron, golden Goddess) is a perennial herbaceous aromatic plant from the ginger family (Zingiberaceae). It is assumed that turmeric originated in China, and Buddhist monks or Chinese migration brought it to the Indian subcontinent. Anyway, turmeric is nowadays cultivated in Asian countries (Bangladesh, China, Thailand, Cambodia, Malaysia, Indonesia, Philippines) and some parts of South America (Peru and Bolivia) but India still remains the largest producer, consumer and exporter [5]. The plant has yellow flowers and reaches a height of about $1 \mathrm{~m}$. The underground rhizome is yellowish, consisting of two main parts: the egg-shaped (mother) rhizome and the long cylindrical, branched primary, secondary and even tertiary rhizomes
$[6,7]$. Turmeric rhizome contains two major classes of secondary metabolites: phenolic curcuminoids and essential oil [8]. These metabolites are largely responsible for the pharmacological effects of turmeric [9]. The composition of the both metabolites depends on a genotype, the environment, harvest season, dry process and storage conditions [10]. Curcuminoids are responsible for the yellow color of the turmeric, and the essential oil that it contains for its aroma and taste [7,11]. The major and the most studied curcuminoid found in turmeric is curcumin, which is recognized as the most responsible compound for the majority of beneficial effects which this miraculous plant exhibits. Besides curcumin, there are two more curcuminoids: demetoxycurcumin and bisdemetoxycurcumin [12]. The essential oil could be obtained from fresh $[9,13,14]$ and dry leaves [15,16], fresh flowers [16], dry roots [16] and fresh $[9,13,17]$ and dry rhizomes $[16,18]$ of turmeric. Dried rhizomes and leaves are used for the essential oil extraction in the industry. Rhizomes (despite the fact that they contain a higher amount of active compounds in comparison to other plant parts) [13] have a higher oil content than leaves, $5-6 \%$ vs. $1-1.5 \%$, respectively [7]. The essential oils from leaves and flowers are dominated by monoterpenes while those from roots and rhizomes primarily contained sesquiterpenes

\footnotetext{
*Author address: Ljiljana Stanojević, Faculty of Technology,

Bulevar oslobodjenja 124, 16000 Leskovac, Serbia

E-mail: ljiljas76@yahoo.com

The manuscript received: July, 07, 2015.

Paper accepted: September, 18, 2015
} 
[19]. The major volatile principles of the rhizome oil are $\alpha$ - and $\beta$-turmerone and ar-turmerone [10].

Turmeric use dates from even 6000 years ago. It exhibits many beneficial effects because of phytochemicals that it contains and some of them are: anti-carcinogenic, anti-inflammatory, anti-microbial [20], anti-fungal [21], anti-mutagenic [22], hypocholesteremic, insect repellent, anti-rheumatic, anti-fibrotic, anti-venomous, anti-diabetic, anti-viral, anti-hepatotoxic [5]. Turmeric was (and is) used for religious proposes (as an amulet) in the Hindu culture; as spice and food colorant (because of its flavor and golden color) and a food preservative in India; in Ayurveda (traditional Indian medicine) it is used orally as stomachic and blood purifier, to treat gall bladder and heart problems, liver disorders, bloating, menstrual problems, disorders of the urinary tract, allergies, arthritis and other chronic diseases [11], topically in the treatment of various skin diseases $[11,19]$ and via inhalation in treating chronic rhinitis and coryza [19].

The main objectives of this study were to determine the chemical composition of the essential oil obtained from the turmeric rhizome by Clevenger hydrodistillation using GC-MS method, as well as its antioxidant activity using DPPH assay, and antimicrobial activity using a disc-diffusion method in order to contribute to the greater use of turmeric in pharmaceutical and food industry in the southeast Serbia. Although many researchers worked on the isolation and characterization of turmeric essential oil, according to the literature cited in this paper, the determination of the chemical composition and investigation of the biological activity of the essential oil isolated from the commercial spice originated from Turkey has not been done yet. This is reasonable to some extent, having in mind the fact that Turkey is not in the top list of the turmeric producer and consumer countries.

\section{Experimental}

\section{Plant material}

A fine, yellow turmeric powder (commercial spice) obtained from the dry, ground turmeric rhizome (Rhizoma Curcumae) was purchased from the local health food store in Vlasotince, Serbia. According to the declaration it originates from Turkey (importer: Balkan Komerc; packed by: BIOTIKA d.o.o. Beograd, Bulevar Vojvode Mišića 37-39 in collaboration with RADAKOVIĆ CO d.o.o. Vršac).

\section{Reagents and chemicals}

Ethanol, 96\% (Centrohem, Zemun, Serbia), 1.1-diphenyl-2-picrylhydrasil (DPPH radical), butylated hydroxytoluene (BHT) (Sigma Chemical Company, St. Louis, USA), dimethyl sulfoxide (DMSO; BDH, Milan, Italy).

Isolation of the essential oil

Essential oil was obtained by Clevenger hydrodistillation, with hydromodulus $1: 5 \mathrm{~m} / \mathrm{V}$ during 180 minutes. The amount of the essential oil was determined per $100 \mathrm{~g}$ of the plant material. The obtained oil was dried over anhydrous sodium sulfate and kept at $4{ }^{\circ} \mathrm{C}$ until analysis.

\section{GC-MS and GC-FID analysis}

GC-MS analysis of the essential oil obtained from turmeric rhizome was performed on Agilent Technologies 7890B gas chromatograph, equipped with weakly polar, silica capillary column, HP-5MS (5\% diphenyl- and 95\% dimethyl-polysiloxane, $30 \mathrm{~m} \times 0.25 \mathrm{~mm}, 0.25 \mu \mathrm{m}$ film thickness; Agilent Technologies, USA) and coupled with inert, selective 5977A mass detector of the same company. One $\mu$ l of the sample dissolved in diethyl ether in the concentration of 500 ppm was injected in 20:1 split mode. Helium was used as the carrier gas, at a constant flow rate of $1 \mathrm{~cm}^{3} / \mathrm{min}$. The oven temperature was programmed from $50{ }^{\circ} \mathrm{C}$ for 2.25 minutes and then increased to $290{ }^{\circ} \mathrm{C}$ at the rate of $4{ }^{\circ} \mathrm{C} / \mathrm{min}$. Temperatures of the MSD transfer line, ion source and quadruple mass analyzer were set at $300{ }^{\circ} \mathrm{C}, 230^{\circ} \mathrm{C}$ and $150{ }^{\circ} \mathrm{C}$, respectively. The ionization voltage was $70 \mathrm{eV}$ and mass range $\mathrm{m} / \mathrm{z}$ 35-650.

GC-FID analysis was carried out under identical experimental conditions as GC-MS. The temperature of the flame-ionization detector (FID) was set at $300{ }^{\circ} \mathrm{C}$.

Data processing was performed using MSD ChemStation, MassHunter Qualitative Analysis and AMDIS 32 softwares (Agilent Technologies, USA). Retention indices of the components from the analyzed samples were experimentally determined using a homologous series of n-alkanes from C8-C20 as standards. Compounds identification was based on the comparison of their retention

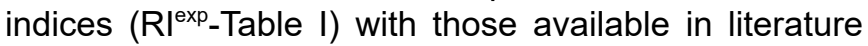
$[23,24]$ (Rlit-Table I), as well as their mass spectra with those from Willey, NIST and RTLPEST libraries. The percentage composition of particular components in the essential oil was determined on the basis of automatically integrated peak areas of the GC-FID signal.

\section{DPPH assay}

The ability of the essential oil to scavenge free DPPH radicals was determined using the DPPH assay. The essential oil was dissolved in ethanol and a series of different concentrations was prepared. The ethanol solution of DPPH radical $\left(1 \mathrm{~cm}^{3}, 300 \mu \mathrm{mol}\right.$ solution $\left.\left(3 \times 10^{-4} \mathrm{~mol} / \mathrm{dm}^{3}\right)\right)$ was added to $2.5 \mathrm{~cm}^{3}$ of the prepared essential oil solutions. The absorption was measured at $517 \mathrm{~nm}$ immediately after adding the DPPH radical and after 20, 30 and 45 minutes incubation with radical. The absorption at 517 $\mathrm{nm}$ was determined for the ethanolic solution of DPPH radical as well, which was diluted in the aforementioned ratio $\left(1 \mathrm{~cm}^{3}\right.$ of the DPPH radical of the given concentration with $2.5 \mathrm{~cm}^{3}$ ethanol added). Ethanol was used as a blank. Free radical scavenging activity was calculated according to the formula: 
DPPH radical scavenging capacity $(\%)=100-\left[\left(A_{\mathrm{S}}-A_{\mathrm{B}}\right) \times \frac{100}{A_{\mathrm{C}}}\right]$

As - Absorption of the "sample" at 517 nm. "Sample" ethanolic solution of the essential oil treated with DPPH radical solution

$A_{\mathrm{B}}$ - Absorption of the "blank" at $517 \mathrm{~nm}$. "Blank" - ethanolic solution of the essential oil which is not treated with DPPH radical solution

Ac - Absorption of the "control" at $517 \mathrm{~nm}$. "Control" ethanolic solution of the DPPH radical

All absorptions were measured on UV-VIS VARIANCary 100 Conc. Spectrophotometer.

The essential oil concentration needed for the neutralization of $50 \%$ of the initial DPPH radical concentration is called EC50 value. This value was determined by using a linear regression analysis in the concentration range between 0.008 and $2 \mathrm{mg} / \mathrm{cm}^{3}$ of the essential oil added to the reaction mixture.

Antimicrobial activity

Microorganisms and mediums

Eight microorganisms were selected to determine the antimicrobial activity of turmeric essential oil: Candida albicans (ATCC 10259), Proteus vulgaris (ATCC 8427), Bacillus cereus (ATCC), Bacillus subtilis (ATCC 6633), Klebsiella pneumoniae (ATCC 700603), Staphylococcus aureus (ATCC 25923), Escherichia coli (ATCC 25922) and Listeria monocytogenes (ATCC 19166). Mediums used for the growth of the microorganisms: nutrient agar for bacterial growth and Sabouraud maltose agar (Torlak, Belgrade) for fungi. Microorganisms are from the collection of the Microbiology Laboratory, Faculty of Technology, Leskovac.

\section{Disc-diffusion method}

The agar disc-diffusion method was used for testing the antimicrobial activity of turmeric essential oil [25]. The mediums were sterilized for 15 minutes in an autoclave at $121{ }^{\circ} \mathrm{C}$ under $110 \mathrm{kPa}$.

An inoculum of $0.1 \mathrm{~cm}^{3}$ of overnight culture was added to $10 \mathrm{~cm}^{3}$ of the medium and poured into petri dishes. For screening, sterilised filter paper disks $(12.7 \mathrm{~mm}$ dia., Schleicher\&Schuell) were placed on the surface of inoculated mediums and impregnated with $60 \mu \mathrm{l}$ of the essential oil (1:10 V/V in DMSO). The plates were incubated for 24 hours at $37{ }^{\circ} \mathrm{C}$ for bacteria, and 48 hours at $25{ }^{\circ} \mathrm{C}$ for fungi. After incubation, the inhibition zone diameters were measured and expressed in $\mathrm{mm}$. The presence of the inhibition zone indicates the activity of the tested samples against bacteria or fungi.

Standardized discs of Ampicilin (10 $\mu \mathrm{g} / \mathrm{disc})$, Bactrim (25 $\mu \mathrm{g} / \mathrm{disc})$, Cefalexin (30 $\mu \mathrm{g} / \mathrm{disc})$ (Bio Rad) and Nystatin (100 U/disc) (Bioanalyse) were used as reference standards. DMSO was used as negative control.

\section{Results and Discussion}

Qualitative and quantitative essential oil composition

The essential oil from the ground turmeric rhizome (turmeric spice) was isolated by Clevenger hydrodistillation. The yield of the essential oil was $0.3 \mathrm{~cm}^{3}$ per $100 \mathrm{~g}$ plant material. GC-MS analysis resulted in identifying eight compounds: eugenol, $(E)$-cariophyllen, curcumen, $\alpha$-zingiberene, $\beta$-sesquiphelandrene, ar-turmerone, turmerone and curlone, representing $82.9 \%$ of the total oil composition.

Table 1. Chemical composition of the essential oil from turmeric rhizome

\begin{tabular}{|c|c|c|c|c|c|}
\hline Peak & $t_{\text {ret. }}, \min$ & $\begin{array}{c}\text { Component } \\
\text { Benzene derivatives }(8 \%)\end{array}$ & $\mathrm{R}^{\mathrm{exp}}$ & $\mathrm{RI}^{\text {lit }}$ & Composition (\%) \\
\hline 1 & 24.8766 & $\begin{array}{c}\text { Eugenol } \\
\text { Sesquiterpene Hydrocarbons (9.5\%) }\end{array}$ & 1360 & $1356^{a}$ & 8 \\
\hline 2 & 26.9897 & (E)-Caryophyllene & 1427 & $1417^{\mathrm{a}}$ & 2 \\
\hline 3 & 28.8137 & ar-Curcumene & 1487 & $1479^{a}$ & 1.8 \\
\hline 4 & 29.1743 & $\alpha$-Zingiberene & 1499 & $1493^{a}$ & 2.8 \\
\hline 5 & 30.0380 & $\begin{array}{c}\beta \text {-Sesquiphellandrene } \\
\text { Oxygenated sesquiterpenes ( } 65.4 \%)\end{array}$ & 1529 & $1521^{a}$ & 2.8 \\
\hline 6 & 34.0390 & ar-turmerone & 1671 & $1668^{a}$ & 22.7 \\
\hline 7 & 34.1516 & Turmerone & 1675 & $1674^{b}$ & 26 \\
\hline 8 & 35.0389 & Curlone & 1708 & $\begin{array}{r}1706^{b} \\
\text { Total }\end{array}$ & $\begin{array}{c}16.8 \\
82.9 \%\end{array}$ \\
\hline
\end{tabular}

tret.: Retention time; $\mathrm{R}$ lit a,b-Retention indices from literature [23,24], respectively; Rlexp: Experimentally determined retention indices using a homologous series of n-alkanes (C8-C20) on the HP-5MS column.

All identified compounds were designated by numbers from 1-8 according to their elution order and classified into benzene derivatives, sesquiterpene (C15) hydrocarbons and oxygenated sesquiterpens together with their percentage compositon given in Table 1. The structures of the identified components are given in Figure 1.

The major compounds were oxygenated sesquiterpenes comprising up to $65.4 \%$ represented by turmerone, ar-turmerone and curlone (Table 1), followed by benzene derivatives with $8 \%$ and sesquiterpene hydrocar- bons with $9.5 \%$ of the total oil composition. Leela and coworkers [16] obtained simular results. Namely, they used fresh flowers and dried leaves, root and rhizome from Curcuma longa for obtaining essential oils by Clevenger hydrodestilation. The major components in the essential oil from dried rhizome were ar-turmerone, turmerone, curlone and ar-curcumene. On the other side, Awasthi and Dixit [13] isolated the essential oil from the fresh turmeric rhizomes. The major components were ar-turmerone, $\beta$-turmerone and $(Z)-\beta$-ocimene. 
Regarding the composition of the essential oil obtained from the dried rhizomes grown in India, the major components were ar-turmerone, curlone, turmerone and ar-curcumene [16] while in the oil obtained from the dried turmeric rhizomes grown in China they were arturmerone, humulene oxide and $\beta$-selinene [18]. It could be concluded that the turmeric essential oil compositon, among many other factors, depends on geographic origin and part of the plant used.

Turmerone and ar-turmerone are, according to their chemical structure, ketonic sesquiterpenes of the bisabolane type responsible for turmeric aroma and smell [10]. Besides contributing to the turmeric organoleptic properties, turmerone posseses a wide range of pharmacological activities such as antioxidant, anti-inflammatory, anti-tumor, anti-proliferative and anti-depressant activity [26]. Ar-turmerone exhibits the mosquito repellent activity and it is an effective drug for the respiratory diseases treatment [27]. Curlone is used against hepatitis [27],
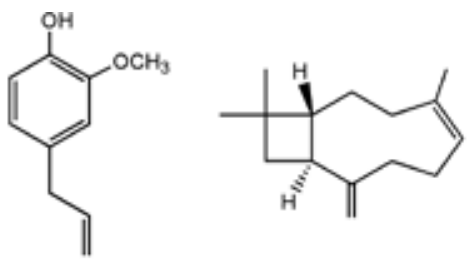

Eugenol

E-Caryophyllene
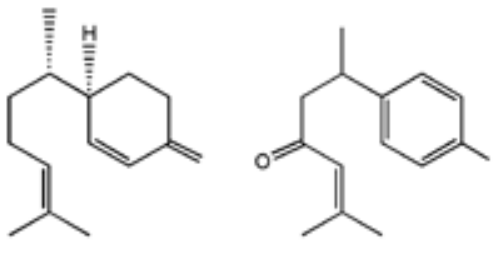

13-Sesquiphellandrene

ar-Turmerone

and allylbenzene eugenol is well known for its antibiotic properties [14]. Curcumin, on the other side, belongs to the group of curcuminoids i.e. diphenylheptanoids (low molecular weight polyphenols) and, as already mentioned, it is the most active and the most studied turmeric component. It acts as an antioxidant due to the capability to scavenge free radicals such as superoxide anions and hydroxyl radicals which are well known as potent initiators of lipid peroxidation. Among many other beneficial effects, curcumin exhibits the anti-inflammatory, anti-protozoal, anti-HIV and anti-tumor activity [12]. All these effects are due to the presence of hydroxyl and phenol groups, as well as the $\beta$-dicarbonylic system with conjugated double bonds (dienes). The mentioned system provides lipophylicity thus enabling curcumins' better skin and blood-brain barrier penetration. Curcumin is also well known as food colouring agent, with $E$ number E100 [11,12].
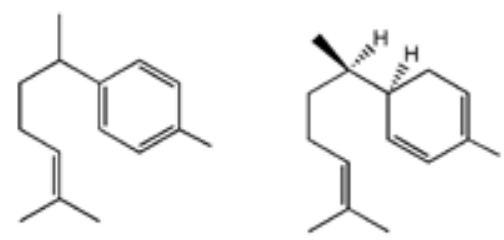

ar-Curcumene

$\alpha$-Zingiberene
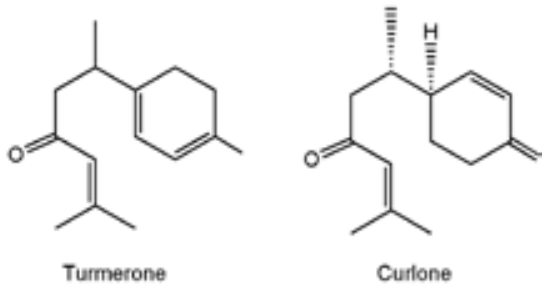

Figure 1. Structures of the identified components in turmeric essential oil

Antioxidant activity

The antioxidant activity of the obtained essential oil was studied using DPPH assay. DPPH radical absorbs at $517 \mathrm{~nm}$ (violet in color). When exposing the radical to free radical scavengers its absorbance significantly decreases because of the hydrogen atom transfer from the antioxidant to the radical. Thereby, the absorbance decrease indicates on the antioxidant potential of the studied sample.

DPPH radical neutralization capacity depends on the applied oil concentration, as well as on the incubation time - it increases with the concentration of the not-incubated samples, while in the case of incubated samples this increase was up to the oil concentration of $0.5 \mathrm{mg} / \mathrm{cm}^{3}$ (the oil concentration added to the reaction mixture) and slightly increased later. The oil showed the best antioxidant activity (with the degree of DPPH radical neutralization of $92 \%$ ) after 45 minutes of incubation. The oil incubated for 20 and 30 minutes showed a slightly lower degree of the DPPH radical neutralization in the same concentration (91.8\%, for the both oils). On the other side, the oil which was not incubated showed a considerably lower value, $54.4 \%$ (Figure 2.).

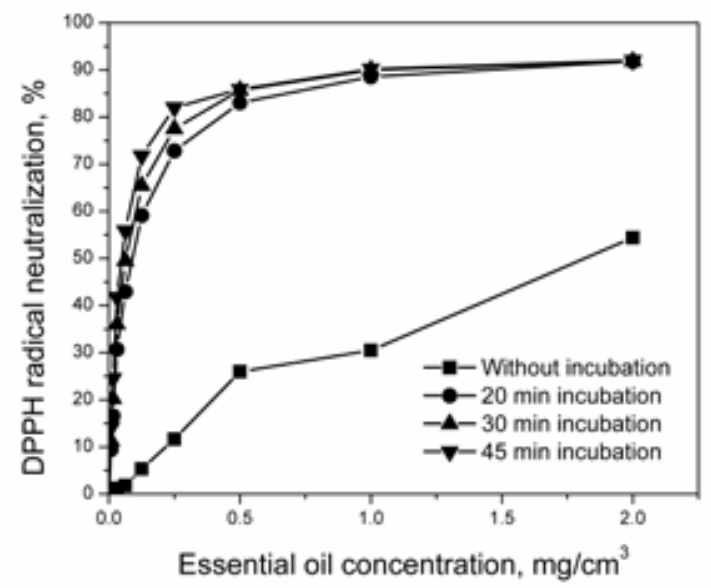

Figure 2. Antioxidant activity of the turmeric rhizome essential oil obtained using Clevenger hydrodistillation 
Oil concentrations needed for the neutralization of $50 \%$ of the initial DPPH radical concentration (EC50 value) were $1.784 \mathrm{mg} / \mathrm{cm}^{3}$ (without incubation); $0.098 \mathrm{mg} /$ $\mathrm{cm}^{3}$ (after 20 minutes); $0.072 \mathrm{mg} / \mathrm{cm}^{3}$ (after 30 minutes) and $0.045 \mathrm{mg} / \mathrm{cm}^{3}$ (after 45 minutes incubation with radical). The synthetic antioxidant BHT showed EC50 value of $0.021 \mathrm{mg} / \mathrm{cm}^{3}$ after 20 minutes incubation with DPPH radical. Since BHT is one of the most used antioxidant but with deleterious effects on the human organism [28], based on the obtained results it could be concluded that the turmeric essential oil obtained in this study may be considered as a safer alternative to the synthetic antioxidants with potential application in pharmaceutical and food products.

Table 2. Antimicrobial activity of the essential oil from turmeric rhizome

\begin{tabular}{|c|c|c|c|c|c|}
\hline \multirow[b]{2}{*}{ Microorganism } & \multirow{2}{*}{ Essential oil } & \multicolumn{4}{|c|}{ Antibiotics } \\
\hline & & $\begin{array}{c}\text { Ampicilin } \\
\text { Inhibition zor }\end{array}$ & $\begin{array}{l}\text { Bactrim } \\
\text { e, } \mathrm{mm}\end{array}$ & Cefalexin & Nystatin \\
\hline Candida albicans & 31 & n.t. & n.t. & n.t. & 17 \\
\hline Proteus vulgaris & 15 & 13.2 & 22.9 & n.t. & n.t. \\
\hline Bacillus cereus & 17 & n.t. & n.t. & n.t. & n.t. \\
\hline Bacillus subtilis & 24 & n.t. & n.t. & 48 & n.t. \\
\hline Klebsiella pneumoniae & 18 & n.t. & n.t. & 13 & n.t. \\
\hline Staphylococcus aureus & n.a. & 36.7 & 42.1 & 26 & n.t. \\
\hline Escherichia coli & n.a. & n.a. & 15.0 & 26 & n.t. \\
\hline Listeria monocitogenes & n.a. & n.t. & n.t. & 34 & n.t. \\
\hline
\end{tabular}

Antimicrobial activity

Turmeric essential oil showed activity upon the majority of the studied microorganisms. The strongest (antifungal) activity was observed on $C$. albicans. Additionally, the inhibition was almost two times stronger comparing with antifungal medication Nystatin $-31 \mathrm{~mm}$ vs. $17 \mathrm{~mm}$, respectively (Table 2.). Candida albicans is a dimorphic fungus that makes normal human microbiota microflora in gastrointestinal and genitourinary tract. It is an opportunistic pathogen that attacks immunocompromised patients (for example after cancer chemotherapy or HIV infections), so candidiasis are very frequent infections. Considering that $C$. albicans is eukaryotic cell, it shares many common biologic properties with humans, so commercial antifungal agents used today cause harmful effects and it is necessary to develop new, more effective natural antifungal agents [29-31]. Considering that $C$. albicans is very persistent microorganism that causes urinary infection so obtained essential oil could be used not only in the preventive but also for therapeutic proposes.

$P$. vulgaris and $K$. pneumoniae belong to Gram-negative bacteria that cause urinary infections [32,33]. The obtained turmeric essential oil showed slightly better $(18 \mathrm{~mm})$ activity against $K$. pneumoniae than cephalosporin antibiotic Cefalexin (13 mm inhibition zone) (Table 2.).

Among Gram-positive bacteria ( $B$. cereus and $B$. subtilis) $B$. subtilis was more sensitive. Bacillus species are responsible for numerous infections in humans due to the consumption of food products rich in starch and proteins, such as for example rice, meat and meat products. These bacteria also caused very serious diseases including meningitis, gangrene and eye infections [34].

The obtained essential oil showed no activity on $S$. aureus, E. coli and L. monocitogenes. Norajit and colleagues [35] extracted the essential oil by hydrodistillation from the fresh turmeric rhizome grown in Thailand. It showed the activity against $S$. aureus, but not against $E$. coli.
Regarding the inactivity of the obtained essential oil against $L$. monocitogenes our results are in agreement with those obtained by Antunes and coworkers [36]. In order to increase the activity of the essential oil against these bacteria they added an antioxidant - ascorbic acid and observed their synergistic action. It should be noted that antimicrobial activity of essential oils depends, among other, on the concentration and the chosen extraction method [37].

Generally, essential oils exhibit a stronger antimicrobial activity on Gram-positive bacteria (comparing to Gram-negative bacteria) because of the presence of lipoteichoic acids, i.e. their lipophilic ends in the (less complex, single-layer) membranes that facilitate the penetration of hydrophobic compounds present in essential oils. These compounds impart crucial processes in the cell due to the increased membrane permeability, consequently inducing leakage of ions and important cell contents, finally leading to the cell death. On the other side, Gram-negative bacteria are resistant thanks to the presence of extrinsic membrane proteins or cell wall lipopolysaccharides, with the ability of limitation of the diffusion rate of hydrophobic compounds through the (more complex, double layered - lipopolysaccharide) cell membrane [2,3].

The antimicrobial activity of the essential oil from turmeric rhizome is probably the consequence of common effects of all components present in the oil. However, it is difficult to compare the data with literature because the variables that influence the results are the essential oil composition and antimicrobial test method used. Moreover, the standard criteria for the evaluation of the plant essential oil activity are missing and therefore the results obtained by different authors are widely different [38]. 


\section{Conclusion}

The essential oil was obtained from the turmeric commercial spice available in the local Serbian market. Eight compounds were identified and quantified by GC-MS and GC-FID analysis: eugenol, (E)-cariophyllen, ar-curcumen, $\alpha$-zingiberene, $\beta$-sesquiphelandrene, ar-turmerone, turmerone and curlone. The composition of the obtained essential oil is very similar to that obtained from the turmeric rhizome grown in India. The major compound in the oil was turmerone (26\%). Turmeric essential oil showed a high degree of DPPH radical neutralization. The concentration of the essential oil needed for neutralization of $50 \%$ of the initial DPPH radical concentration (EC50 value) was $0.045 \mathrm{mg} / \mathrm{cm}^{3}$ (after 45 minutes incubation with radical). A degree of DPPH radical neutralization of $92 \%$ was achieved by $2 \mathrm{mg} / \mathrm{cm}^{3}$ essential oil concentration. The obtained oil showed the best antimicrobial (antifungal) activity on C. albicans. Turmeric use is very rare in the Serbian traditional cuisine. Having in mind the obtained results, use of turmeric is not just reasonable but it should be even favored in the nutrition, as well as in food and pharmaceutical industries processing.

\section{Acknowledgment}

This work is part of the research project "Plant and synthetic bioactive products of new generation" no. TR 34012, financed by the Ministry of Education, Science and Technological Development of the Republic of Serbia.

\section{References}

[1] M. Z. Stanković, LJ. P. Stanojević, Tehnologija lekovitog i začinskog bilja, Tehnološki fakultet, Leskovac, 2014, p. 138.

[2] P. Tongnuanchan, S. Benjakul, Essential oils: extraction, bioactivities, and their uses for food preservation, Journal of Food Science, 79(7) (2014) R1231 - R1249.

[3] S. Burt, Essential oils: their antibacterial properties and potential applications in foods - a review, International Journal of Food Microbiology, 94 (2004) 223 - 253.

[4] F. Bakkali, S. Averbeck, D.Averbeck, M. Idaomar, Biological effects of essential oils - a review, Food and Chemical Toxicology, 46 (2008) 446 - 475.

[5] D. Shrishail, H. K. Harish, H. Ravichandra, G. Tulsianand, S.D. Shruthi, Turmeric: nature's precious medicine, Asian Journal of Pharmaceutical and Clinical Research, 6(3) (2013) $10-16$.

[6] J. Lal, Turmeric, Curcumin and Our Life: A Review, Bulletin of Environment, Pharmacology and Life Sciences, 1 (2012) 11 - 17.

[7] B. Chempakam, V.A. Parthasarathy, in Chemistry of Spices, Ed. V. A. Parthasarathy, B. Chempakam, T. J. Zachariah, CAB International, London 2008, p. 97.

[8] J. L. Funk, J. B. Frye, J. N. Oyarzo, H. Zhang, B. N. Timmermann, Anti-arthritic effects and toxicity of the essential oils of turmeric (Curcuma longa L.), Journal of Agricultural Food Chemistry, 58(2) (2010) 842 - 849.
[9] V. K. Raina, S.K. Srivastava, K.V. Syamsundar, Rhizome and leaf oil composition of Curcuma longa from the lower Himalayan region of Northern India, Journal of Essential Oil Research, 17 (2005) 1 - 4.

[10] S. Li, W. Yuan, G. Deng, P. Wang, P. Yang, B. B. Aggarwal, Chemical composition and product quality control of turmeric (Curcuma longa L.), Pharmaceutical Crops, 2 (2011) 28 - 54.

[11] G. K. Jayaprakasha, Chemical and bioactive studies on byproducts from spice processing. Thesis, Department of Human Resource Development, Central Food Technological Research Institute, University of Mysore, 2003.

[12] M. Akram, Shahab-Uddin, A. Ahmed, K. Usmanghani, A. Hannan, E. Mohiuddin, M. Asif, Curcuma longa and curcumin: a review article, Romanian Journal of Biology - Plant Biology, 55(2) (2010) p. 65 - 70.

[13] P. K. Awasthi, S. C. Dixit, Chemical composition of Curcuma longa leaves and rhizome oil from the plains of Northern India, Journal of Young Pharmacists, 1(4) (2009) 312 - 316.

[14] Z. Adnan, Z. Noer , Zulzannah, Analysis of essential oil components from fresh leaves of Piper crocatum Ruiz \& Pav. and Curcuma domestica Val., Majalah Farmasi dan Farmakologi, 15(1) (2011) 17 - 22.

[15] R. Priya, A. Prathapan, K. G. Raghu, A. Nirmala Menon, Chemical composition and in vitro antioxidative potential of essential oil isolated from Curcuma longa L. leaves, Asian Pacific Journal of Tropical Biomedicine, (2012) S695-S699.

[16] N. K. Leela, A. Tava, P. M. Shafl, S. P. John, B. Chempakam, Chemical composition of essential oils of turmeric (Curcuma longa L.), Acta Pharmaceutica, 52 (2002) 137 - 141.

[17] K. Norajit, N. Laohakunjit, O. Kerdchoechuen, Antibacterial effect of five Zingiberaceae essential oils, Molecules, 12 (2007) 2047-2060.

[18] S.-Y. Tsai, S.-J. Huang, C.-C. Chyau, C.-H. Tsai, C.-C. Weng, J.-L. Mau, Composition and antioxidant properties of essential oils from Curcuma rhizome, Asian Journal of Arts and Sciences, 2(1) (2011) 57-66.

[19] A. O. O. Ongwesa, M. Syed Ali, N. Yogananth, V. Anuradha, M. Ferosekhan, M. Munees Prabu, Safety and efficacy of essential oil from Curcuma longa against Aedes aegypti and Anopheles stephensi mosquito vectors, International Journal of Comprehensive Research in Biological Sciences, 1(1) (2014) 36 - 43.

[20] P. M. Reddi, A Touch of Turmeric: Examining an Ayurvedic Treasure, Advances in Anthropology,3(2) (2013) 91 - 95.

[21] R. Sharma, G. Sharma, M. Sharma, Additive and inhibitory effect of antifungal activity of Curcuma longa (Turmeric) and Zingiber officinale (Ginger) essential oils against Pityriasis versicolor infections, Journal of Medicinal Plants Research, 5(32) (2011) 6987 - 6990.

[22] V. B. Liju, K. Jeena, R. Kuttan, Chemopreventive activity of turmeric essential oil and possible mechanisms of action, Asian Pacific Journal of Cancer Prevention, 15(16) (2014) 6575 - 6580.

[23] R. P. Adams, Identification of essential oil components by gass chromatography/mass spectrometry, 4th Ed. Allured Publishing Corporation, Illinois 2007.

[24] S.-L. Hong, G.-S. Lee, S. N. S. A. Rahman, O. A. A. Hamdi, K. Awang, N. A. Nugroho, S. N. A. Malek, Essential oil content of the rhizome of Curcuma purpurascens $\mathrm{Bl}$. 
(Temu Tis) and its antiproliferative effect on selected human carcinoma cell lines, The Scientific World Journal, Article ID 397430, 2014 (2014) 1-7.

[25] J. A. Kiehlbauch, G. E. Hannett, M. Salfinger, W. Archinal, C. Monserrat, C. Carlin, Use of the National Committee for Clinical Laboratory Standards Guidelines for Disk diffusion susceptibility testing in New York State Laboratories, Journal of Clinical Microbiology, 38(9) (2000) 3341 - 3348.

[26] J.-C. Liao, J.-C. Tsai, C.-Y. Liu, H.-C. Huang, L.-Y. Wu, W.-H. Peng, Antidepressant-like activity of turmerone in behavioral despair tests in mice, BMC Complementary and Alternative Medicine, 13(1) (2013) 299.

[27] G. K. Jayaprakasha, B. S. Jena, P. S. Negi, K. K. Sakariah, Evaluation of antioxidant activities and antimutagenicity of turmeric oil: a byproduct from curcumin production, Zeitschrift für Naturforschung C, 57(9-10) (2002) 828 835.

[28] N. Ito, M. Hirose, H. Fukushima, T. Tsuda, T. Shirai, M.Tatenatsu, Studies on antioxidants: their carcinogenic and modifying effects on chemical carcinogens, Food and Chemical Toxicology, 24 (1986) 1071 - 1092.

[29] G. Molero, R. Díez-Orejas, F. Navarro-García, L. Monteoliva, J. Pla, C. Gil, M. Sánchez-Pérez, C. Nombela, Candida albicans: genetics, dimorphism and pathogenicity, International Microbiology 1 (1998) 95 - 106.

[30] A. Kumar, S. Thakur, V. C. Thakur, A. Kumar, S. Patil, M.P Vohra Antifungal activity of some natural essential oils against Candida species isolated from blood stream infection, Journal of Krishna Institute of Medical Sciences University, 1(1) (2012) 61 - 66.

[31] J. Berman, P. E. Sudbery, Candida albicans: a molecular revolution built on lessons from budding yeast, Nature Reviews Genetics, 3(12) (2002) 918 - 930.
[32] J. K. Pandey, A. Narayan, S. Tyagi, Prevalence of Proteus species in clinical samples, antibiotic sensitivity pattern and ESBL production, International Journal of Current Microbiology and Applied Sciences, 2(10) (2013) 253 261.

[33] C. Vuotto, F. Longo, M. P. Balice, G. Donelli, P. E. Varaldo, Antibiotic resistance related to biofilm formation in Klebsiella pneumonia, Pathogens, 3 (2014) 743 - 758.

[34] A. Kotironta, K. Lounatma, M. Haapasolo, Epidemology and pathogenesis of Bacillus cereus infections, Microbes and infection, 2 (2000) 189 - 198.

[35] K. Norajit, N. Laohakunjit, O. Kerdchoechuen, Antibacterial effect of five Zingiberaceae essential oils, Molecules, 12 (2007) 2047 - 2060.

[36] S. A. Antunes, W. da Silva Robazza, L. Schittler, G. de Almeida Gomes, Synergistic and antimicrobial properties of commercial turmeric (Curcuma longa) essential oil against pathogenic bacteria, Ciência e Tecnologia de Alimentos, 32(3) (2012) 525 - 530.

[37] F. Gardini, N. Belletti, M. Ndagijimana, M. E. Guerzoni, F. Tchoumbougnang, P. H. Amvam Zollo, C. Micci, R. Lanciotti, S. L. Sado Kamdem, Composition of four essential oils obtained from plants from Cameroon, and their bactericidal and bacteriostatic activity against Listeria monocytogenes, Salmonella enteritidis and Staphylococcus aureus, African Journal of Microbiology Research, 3(5) (2009) 264 - 271.

[38] Lj. Stanojević, M. Stanković, M. Cakić, V. Nikolić, Lj. Nikolić, D. Ilić, N. Radulović, The effect of hydrodistillation techniques on yield, kinetics, composition and antimicrobial activity of essential oils from flowers of Lavandula officinalis L., Hemijska Industrija, 65(4) (2011) $455-463$.

Izvod

\section{HEMIJSKI SASTAV, ANTIOKSIDATIVNA I ANTIMIKROBNA AKTIVNOST ETARSKOG ULJA KURKUME (Curcuma longa L.)}

Jelena S. Stanojević, Ljiljana P. Stanojević, Dragan J. Cvetković, Bojana R. Danilović

Tehnološki fakultet, Leskovac, Srbija

Ovaj rad se bavi ispitivanjem etarskog ulja dobijenog iz samlevenog rizoma kurkume (Rhizoma Curcumae) (Turska) Clevenger hidrodestilacijom pri hidromodulu $1: 5 \mathrm{~m} / \mathrm{V}$ u toku 180 minuta. Kvalitativni i kvantitativni sastav ulja je određen GC-MS i GC-FID spektrometrijom. Antioksidativna aktivnost dobijenog ulja je određena DPPH testom odmah nakon dodavanja DPPH radikala i nakon 20 min, $30 \mathrm{~min}$ i 45 min inkubacije sa radikalom. Antimikrobna aktivnost je određena diskdifuzionom metodom. Prinos etarskog ulja iznosi $0,3 \mathrm{~cm}^{3} / 100 \mathrm{~g}$ biljnog materijala. U ulju je identifikovano osam komponenti. Najzastupljenije komponente su ar-turmeron (22,7\%), turmeron (26\%) i kurlon (16,8\%). Najbolju antioksidativnu aktivnost je pokazalo ulje inkubirano 45 minuta sa DPPH radikalom. EC50 vrednosti etarskog ulja iznose $1,784 \mathrm{mg} / \mathrm{cm}^{3}$ (bez inkubacije), $0,098 \mathrm{mg} / \mathrm{cm}^{3}$ (nakon 20 minuta), $0,072 \mathrm{mg} / \mathrm{cm}^{3}$ (nakon 30 minuta) i $0,045 \mathrm{mg} / \mathrm{cm}^{3}$ (nakon 45 minuta inkubacije sa radikalom). Dobijeno etarsko ulje je pokazalo najbolju antimikrobnu (antifungalnu) aktivnost na Candidu albicans. Dobijeni rezultati pokazuju da je etarsko ulje kurkume izuzetno jak antioksidans i antimikrobni (antifungalni) agens sa potencijalnom primenom u prehrambenoj i farmaceutskoj industriji kao bezbednija alternativa sintetskim antioksidansima $i$ antimikrobnim agensima.
(ORIGINALNI NAUČNI RAD) UDK 633.8:665.5:66.048.6

Ključne reči: Curcuma longa L., Clevenger hidrodestilacija, antioksidativna aktivnost, antimikrobna aktivnost, GC-MS 